\title{
CULTURAL DIVERSITY AND SUBSIDIARITY: THE CASE OF CULTURAL TOURISM IN THE EUROPEAN UNION ${ }^{1}$
}

\author{
Elisabeth Dumont and Jacques Teller
}

\begin{abstract}
This article takes the example of cultural tourism to highlight the specificities of European Cultural Policies. It argues, that, although it is often presented as a way of supporting a diversity of approaches, styles and objectives, the subsidiarity principle can sometimes endanger the cultural diversity it seeks to protect. Tourism for instance, has long been considered as a self-regulating activity and cultural tourism is often seen as 'sustainable by nature'. Experience however shows that local authorities often lack an understanding of all the intricacies and consequences of cultural tourism development. Without proper tools for assessing and preventing negative impacts, local actors may lose control over its development, miss on benefits and endanger the diversity of cultures currently existing and co-existing in the European Union.
\end{abstract}

${ }^{1}$ Many thanks to members of the staff of the Committee for Culture and Education at the European Parliament for agreeing to answer our questions. Many thanks to all the experts interviewed in the context of PICTURE and those that returned a questionnaire. This article has been prepared in the framework of the PICTURE project 'Pro-active management of the Impact of Cultural Tourism upon Urban Resources and Economies'. The PICTURE project is financed by the European Commission, Sixth Framework Programme of Research, under the theme 'Policy support and anticipating scientific and technological needs', Priority 3 'Underpinning the economic potential and cohesion of a larger and more integrated European Union', Topic 3.6. 'The protection of cultural heritage and associated conservation strategies'. The contract number of the PICTURE project is SSP1-CT-2003-502491. 


\section{Introduction}

Cultural tourism is the form of tourism that has the highest growth expectations (ATLAS 2005; Ashworth 2001) in an industry that is now number one in the world and the fastest growing economic sector, in terms of foreign exchange earnings and job creation (WTO 2004). Cultural tourism is located at the nexus of the process of globalisation of culture and that of fragmentation of culture and reinforcement of local identities. As a transversal activity, its development involves a variety of stakeholders with different backgrounds and different experiences. This position and array of backgrounds mean on the one hand, that tourism development often proves intricate, with diverging points of views, conflicts of interests and power relations and, on the other hand, that regulation will have to take into account the diversity of the enterprise and the diversity of cultures tourism brings together.

This article takes the example of cultural tourism to highlight the specificities of European Cultural Policies. The European Union considered it was not the role of an international institution to define the notion of culture. The European Union further argues that its originality lies in the diversity of its cultures, a position reflected in the motto recently proposed in the project of European Constitution - 'United in Diversity.' One could question whether Europe proves more culturally diverse than other continents or whether referral to this concept hides the current difficulty to adopt voluntary cultural policies at European level. The article hence starts with an introduction to the difficulty of agreeing on common definitions of politically charged notions such as culture, cultural tourism or cultural diversity. Throughout, it will look at cultural diversity as the peaceful co-existence, respect and equal value given to all types of culture and their expressions in the Union. It will also consider how cultural tourism and EU policies facilitate or hinder the protection of or quest for cultural diversity.

After discussing key concepts, the article will move to end users' expectations from the European Union in cultural policies at large and more specifically in the development of cultural tourism, based on results from surveys carried out at a European level. Although culture was not explicitly part of the Treaty of Rome establishing the European Economic Community in 1957, it can be argued that the mere idea of Europe is both a common heritage and a cultural project. The Treaty of Maastricht in 1992 definitively acknowledged this dimension of the 
European construction and established competencies of the European Union in the domain of culture. The Maastricht treaty, as well as the 1996 first report on the consideration of cultural aspects in European community action, the 1996 cohesion policy and culture first framework programme in support of culture (2000-2004) will be more specifically discussed.

The action of the European Union in the domains of culture and cultural tourism still remains limited by the subsidiarity principle, which leaves the initiative to set up cultural policies to local operators (countries, regions, municipalities or private actors). Although it is presented as a way of supporting a diversity of approaches, styles and objectives, these actors often lack the tools to ensure that their policies will in fact not harm cultural diversity, or else, they may have agendas other than the protection of diversity. Experience in cultural tourism indeed shows that without proper tools for assessing and preventing negative impacts of tourism, local actors may lose control over its development and miss on benefits. The paper will then argue, that, if rights come with duties, duties also come with rights and, even if not obligatory, guidance should be provided to help countries and municipalities face their duties and foster sustainability, while allowing respect for local specificities.

\section{Politics of Definition and Difficulties of Implementation}

The preservation of cultural heritage falls under the scope of numerous European Union policies. First and foremost Article 151 of the Treaty (ex. Article 128) states that 'The Community shall contribute to the flowering of the cultures of the Member States, while respecting their national and regional diversity and at the same time bringing common cultural heritage to the fore'.

The concept of Culture proves very difficult to define. It varies dramatically in space and time and it is often stamped with subjectivity. As stated in European Commission documents, 'it is not for an institution to define the content of the concept of culture' (CEC, 1996 a). According to UNESCO, 'culture consists of all distinctive, spiritual and material, intellectual and emotional features which characterise a society or a social group' (UNESCO 1982). This definition seems very broad, possibly too much to be operational in any way. It nevertheless reflects the fact that, for these institutions, 'culture is no longer restricted to "high- 
brow" culture (...). Today the concept also covers popular culture, massproduced culture, everyday culture' (CEC, 1998).

As a concept, tourism does not meet unanimity either. Consultants in tourism and statistics makers would tend to define it as a travel with at least one night away from home, while local authorities or politicians tend to include day-trippers and locals in tourism. This has an influence on the definition of policies and understanding of statistics. In Venice, for instance, 68,9\% of all tourism comes from excursionists (Manente \& Rizzi, qtd. UNESCO 1994). Disregarding them would seriously impede any work on carrying capacity. Without a proper understanding of the concepts and a minimum of agreement on them, all different stakeholders will find it very hard to communicate, reach agreement and face the challenges of tourism development, protection of cultural diversity being one of them.

As cultural tourism is made up of two notions hard to circumscribe such as culture and tourism, it proves very difficult to address at a European-wide level. Definitions of cultural tourism abound among official tourist instances, statistics makers, policy makers, research groups and on the Internet. Some of them focus on the supply-side, some of them on the demand side of this market. Some refuse to categorise or include many restrictions and risk becoming too broad (eg: ICOMOS, International Tourism Charter, 2002) while others prove very specific, intending to allow a market analysis, but risking leaving out many facets of cultural tourism (eg: ATLAS 1995).

In the context of the PICTURE project ${ }^{2}$, experts' interviews were used to elaborate a bottom-up (coming from field work rather than from literature) definition of cultural tourism. Interviews were carried out in different countries (mainly European) such as Belgium, France, the Netherlands, Spain but also, for instance Lebanon, with experience in their region of origin or/and others. Their fields of expertise, though all in one way or another related to cultural tourism, varied from town planning, infrastructure and architecture, to local involvement, passing through heritage, archaeology, tourism in itself, economy or culture. Their level of decision-making was local, regional, national or supranational, and they originated from the public (elected or not) and private sector. Yet, in spite of the diversity in these profiles, they all, without

2 Pro-active management of the Impact of Cultural Tourism upon Urban Resources Economies. See www.picture-project.com. 
exception, showed unease when asked to give their own definition. The fact is they all expressed an agenda in their replies. Discourse is power as Foucault argued. Giving a definition means including certain things, aspects and leaving out some others. This usually takes place on the basis of what turns out more convenient for the speaker, whether this careful selection be conscious or unconscious. ${ }^{3}$

Delineating cultural tourism depends on many factors such as the purpose of the definition (understanding the concept, defining the scope of what should be included in the term, allow the production of statistics, ...), the background (origin, education, etc.), the position (tourism professional or heritage conservationist) and the purpose (for instance, making cultural assets profitable versus protecting them) of the people producing the definition. Even though it is important to agree on meaning, it is also important to be aware of the difficulties and political implications of giving a definition (Dumont, Ruelle, Teller, 2005).

The concept of cultural diversity poses the same type of challenges. In its Human Development report, UNDP explains that individuals can have multiple identities that are complementary : ethnicity, language, religion and race, as well as citizenship'(2004:2). It further gives examples of gender and politics. In its universal declaration on cultural diversity, UNESCO avoids giving a definite list where choices may be considered political. Rather, it defines cultural diversity as 'the value through which differences are mutually related and reciprocally supportive'(2000:13). If this concept is used and debated in academic, human rights and international cultural circles, its malleability renders it hard to use it for demonstrations or applications. In this paper cultural diversity will be used to refer to the diversity of cultures found in the European Union, between countries and within countries.

The European Commission has been directly involved in the negotiation about UNESCO's Convention on the Protection and the Promotion of the Diversity of Cultural Expressions, and the ratification of the convention by the European Union is now under way. Ratification would undoubtedly reinforce the weight of culture in European Institutions, as

${ }^{3}$ For more information on the difficulty to define cultural tourism, see Dumont, Teller, Origet du Clouzeau. 2005. 'Pour une definition européenne du tourisme culturel' in Espaces, 231, novembre: 14-17, or Dumont, Ruelle, Teller. 2004. 'Circumscribing cultural tourism: Towards a criteria-based approach'. Picture Position Paper to be downloaded on www.picture-project.com. 
the convention requires parties to consider the objectives of cultural diversity and the terms of the Convention when applying and interpreting their trade obligations. It is hence consistent with existing policies, whose focus is already placed on the protection and promotion of European cultural diversity. Given the ethnic variety of other continents or nations (for instant Vietnam that counts about 50 different population groups) it is questionable whether Europe proves more culturally diverse than other areas of the world. When asked about the relevancy of insisting on the cultural diversity in Europe, a high official of the secretariat of the Committee for Culture and Education at the European Parliament argues that Europe does not exactly prove more diverse than other continents but what makes the difference is the amount of respect and protection of cultural diversity. 'All over the European Continent, diversity is recognised as a good point, as something that deserves respect and protection.' (Interview January 2006).

This care for cultural diversity finds an expression at European level through the principle of cultural exception (even though this mainly concerns economic competition) and through the European institutions internal procedures. The contacts with local population and cultural stakeholders largely rely on the work of European deputies who are expected to bring forward the concerns of their constituencies. With the best of will however, it proves hard for one individual to reflect the diversity of the very large areas that $\mathrm{s} /$ he sometimes represents. Other types of contact thus take place, such as the recently started newsletter for cultural and educational stakeholders, as well as hearings during Parliamentary meetings or meetings between members of Parliament and workers of cultural centres. Associations can request a hearing during Parliamentary meetings or a meeting with members of the secretariat of the Committee for Culture and Education in order to draw attention on existing or subsisting problems, to report on the progress made or suggest new projects. These actions demonstrate the Committee's commitment to participation and respect of cultural diversity, but the form it takes can make it hard for cultural stakeholders not regrouped in an association or without access to official circles to make their voices heard. 


\section{End-users' Expectations in terms of Cultural Tourism}

According to a survey sent to 250 small-and-medium-sized European towns in the context of PICTURE project and 25 direct interviews with professionals directly or indirectly related to tourism, the European Union has an important role to play in tourism development. As one of our experts phrases it: 'reducing the border effect makes it obligatory to reinforce, indeed to adopt regulations and common ways of operating' (Liège, archaeology). ${ }^{4}$

The sample for questionnaires included 250 small-and-medium- sized towns in Europe, covering the different areas of the European Union: East, South, West and North, including candidate countries. It was divided into developing destinations - where local authorities seek to further increase the number of visitors - and mature destinations where the issue is no longer to increase but to manage the number of visitors (eg.: increase the share of overnight tourists or develop carrying capacity measures). Interviews with experts were realised on the basis of semi-conducted direct interviews on a qualitative, explorative mode. A fair representative sample of each country was not sought after. Experts were rather chosen on the basis of their reputation in their respective domains. Diversity was however looked for, not only in the communities of origin but also in the area of expertise, sector and level of decisionmaking or influence (local, regional, national or international). In order to avoid receiving a monolithic image it was decided to interview, along with tourism specialists, experts whose core expertise does not lie in tourism but face its development everyday (town planners, archaeologists, representatives of local neighbourhoods, etc.).

Most towns agree on the role the European Union should play in cultural tourism development. They locate it, on the one hand, in the promotion of networks, exchanges, good practices at supranational or supraregional level and, on the other hand, in funding. About 57\% of towns where tourism is in development and nearly half $(47 \%)$ of mature destinations mention funding. An expert, mayor of a town declared world heritage by UNESCO, confirms this feeling and explains that he spent the first three months in his position looking for European Funds,

4 All quotations in this section come from interviews with experts all over Europe. The town, region or other level of expertise of the expert is mentioned, followed by its domain. 
and that it is these Funds that have allowed him to foster a sustainable development of his town:

I devoted every minute of my first months to a search for European funds. We succeeded in getting some for the rehabilitation of the left side of the river - bring the river closer to town - a project of 1000 millions (pesetas), and the plan terminates exactly in the creation of the future convention centre. Alarza bridge, the convention centre, the environment centre San Seguno, the Hipica, the aim is to regain a lot of things. And the 'INTERREG' for improving accessibility to the historical centre is something else we worked on (Avila, tourism).

Promoting twinning, networks, exchanges between towns with similar typologies, disseminating good practices, experience and expertise in general appear nearly as important. It is brought up by $37 \%$ of towns where tourism is developing and more than half $(52 \%)$ of towns where it is mature. As one expert phrases it 'A network can help to establish a network of experience' (Amiens, heritage). Surprisingly, the more mature a town, the stronger the need for guidance. This probably reflects growing awareness of the challenges of tourism but also means guidance will prove increasingly necessary in a world where tourism grows faster.

Tourism promotion, mainly the sustainable form of tourism, as well as technical and procedural advice, also come to light but to a lesser extent. About $20 \%$ of developing towns insist on the need of guidelines, support, help and a slightly lesser (18,75\%) percentage of mature town agree and mention technical advice. This often relates to EU paperwork that sometimes proves obscure for small municipalities. Yet, mature towns seem to take some distance, put everything into perspective and argue for a European tourism strategy.

Another expert questions this method, since tourism is a world phenomenon and rather argues for diffusion and promotion of knowledge, thus agreeing with the respondents of the questionnaires:

Efforts have not only been European but international, at world level, through charters and so on, (...).. There, we arrive at a problem of, in a way, level of jurisdiction and regulation (...). And to know whether we need to translate these recommendations into laws, including national laws, that's another problem. I can hardly make a comparison; it is (hesitation) how to make something we produce efficient. Well, if we need to do it that way in order to make it efficient, I don't know and actually, I am not sure about it. I think that the main role, to start with, is the diffusion of that type (sustainable) of thinking (Liège, archaeology). 
In the face of the rapid growth of cultural tourism and its correlated challenges, there exists a strong call for a clear definition and regulation that would allow an effective cultural tourism policy at local and global level. We face the paradox of a concept nearly impossible to define and the need to have a clear definition to implement an effective cultural tourism policy, as well as the paradox of one of the biggest economic sector where people are left to their own devices. PICTURE's first answer to this has been to suggest criteria to assess the sustainability of tourism, such as principle of participation (involvement of the local population), principle of precaution (respect of cultural diversity), principle of durability (promote a pro-active approach in order to focus on long-term challenges), principle of integration (respect of the different pillars of sustainable development) (Dumont, Teller, Origet du Clouzeau, 2005). Also, the team is currently developing a framework for the strategic urban governance of cultural tourism and a tool for its impact assessment.

\section{Subsidiarity Principle and EU culture and cultural tourism policies}

The recent acceleration of European integration (common monetary unit, enlargement process etc.) combined with the growing speed of globalisation raised real anxieties among citizens of the Union that what they perceive as their culture, in the broader meaning, may be harmed by foreign or centralised regulation (Sørensen and Vaever, 1992, Cram, 2001, Batt, 2001). Therefore, Article 151 of the Treaty adopts a very cautious approach regarding the subsidiarity principle. Point 5 of this Article explicitly requires that the Council activities be limited to incentive measures, excluding any harmonisation of the laws and regulations of the Member Sates. It also states that the Council shall act unanimously in cultural matters. According to this principle, the European Union will have to act 'as something which guarantees the existence and flowering of cultures rather than something which dilutes the European cultural identities' (CEC, 1998).

Unlike culture, tourism does not constitute a Community policy in itself and, by virtue of the principle of subsidiarity, primarily comes within the remit of the Member Sates. Article 2 of the Treaty lists the promotion of sustainable development of economic activities as one of the Community's tasks. Article 3(u) of the Treaty provides for Community action to comprise measures in the field of tourism for the purposes 
set out in Article 2. Accordingly, the action of the European Union in the domain of tourism has traditionally been conceived as an extension of its wider economic policy, though largely limited to incentives and support programmes.

It was proposed in the Constitutional Treaty to remove the unanimity barrier for decisions relating to culture and to introduce a new title (Article III-281) specifically dedicated to tourism in order to enable the European Union to adopt measures to complement actions within the Member States. Such modifications could prove beneficial for the coherence of the Community's action in the domains of culture and tourism, especially as the European Commission designated cultural tourism as a key area of tourism development in Europe (Richards, 1996). In the meantime the European Union influence on cultural tourism remains largely indirect as it relies on other sectoral policies, such as transport, culture or regional development.

\section{The Culture 2000 Framework and Regional Funds}

Unlike for tourism so far, specific policies for culture exist at European level. The EU adopted its first framework programme, Culture 2000, in support of culture in 1998 (CEC, 1998). It seeks to integrate into a unified framework the different incentive measures scattered until then along three main incentive programmes, Kaleidoscope, Ariane and Raphael. This programme introduces the idea of a European cultural area, 'which is open, varied and founded on the principle of subsidiarity, cooperation between all those involved in the cultural sector, the promotion of a legislative framework conducive to cultural activities and ensuring respect for cultural diversity, and the integration of the cultural dimension into Community policies as provided for in the Article 151(4) of the Treaty' The idea of a common European cultural area promotes the view that most cultural trends in Europe progressively gain a transnational character, while the preservation of cultural diversity and mutual knowledge are obviously very important aspects.

The main objective of the framework programme is the promotion of cultural dialogue as well as mutual knowledge of the cultures and histories of the European peoples. The Culture 2000 Framework hence stresses the role of culture in socioeconomic development in view of ensuring direct recognition of culture as an economic factor and as a drive of social integration and citizenship. Three main types of actions 
were proposed in support of this programme: limited innovative and/or experimental actions (multimedia development, cooperation between cultural and socio-cultural operators for instance); significant integrated actions (mobility of artists, training for instance); and special cultural events (European Capital of Culture for instance).

Six years after the launch of this programme, it is generally accepted that cultural projects are better and more easily supported through European Regional Funds than Culture 2000 fund (FEAP, 2004). This can be explained by the fact that only $0,03 \%$ of the European Union's budget has been allocated to the Culture 2000 programme, while Regional Funds account for over one third of the budget (Pire, 2002). Besides, Regional Funds are primarily directed to support regional development and increase social cohesion. Cultural projects supported by these funds have thus to be based on strong socio-economic objectives, which are often directly or indirectly related to cultural tourism. It has been estimated for instance that, in France, some 10\% of Regional Funds for the period 2000-2006 will directly benefit the tourism sector (Guicheney \& Rouzade, 2004). Arguably the conditions of access to these Regional Funds constitute a very efficient lever to foster a genuine cultural tourism policy respectful of the cultural diversity of European Regions.

\section{Culture and Tourism in other European policies}

The importance and transversality of culture is taken seriously in the EU: whenever an area of EU policy has consequences for culture, the cultural aspect needs to be taken into account (Interview high official in the Committee for Culture and Education at the European Parliament, January 2006). Point 4 of article 151 of the Treaty thereby states that 'the Community shall take cultural aspects into account in its action under other provisions of the Treaty, in particular in order to respect and promote the diversity of its cultures' Point 5 of Article 151 (see above) does not affect the bases on which a number of harmonisation measures with a cultural dimension have already been, and continue to be, taken into account in other EU competency areas. We find among these the social and human resources policy, the cohesion and regional development policy or the competition policy.

A First Report on the consideration of cultural aspects in European Community action was issued by the Commission in 1996 (CEC, 1996 a). It was rapidly followed by a report more specifically addressing the 
impact of cohesion policies on cultural development and derived employment (CEC, 1996 b). The contribution of Structural Funds to the preservation and conservation of cultural heritage is quite important. Funding may be dedicated to projects concerning historic buildings, large industrial remnants or even entire urban historical areas. Yet here again the action of the EU is mostly oriented towards incentive actions and operational projects, not a specifically coordinated policy at European level.

Tourism is also affected by a number of European policies (CEC, 2001), but, unlike cultural matters, tourism is predominantly viewed as an economic activity. It has thus been traditionally addressed by the Enterprise Directorate General of the European Commission. Though, one of the experts interviewed in the PICTURE project explains that even if the industry of tourism is the first provider of jobs in Europe, its fragmented structure (mainly small and local entrepreneurs or retailers) does not allow it to easily reach a strong representation at the European level (Interview Tourism Consultant, mainly at European level)

Two other experts insist on the difficulty to reach an agreement on tourism strategies within Europe, since member states hold most competencies over tourism and do not share common visions about the role of public institutions in its development. Tourism is hence framed by alternative approaches at the moment, allowing some partial influence on policy. However this fragmentation does not allow the development of a true 'Destination Europe' strategy. The organisation of trans-national cultural 'routes' or 'itineraries' represents one solution to the question of sharing expertise and working with different localities on global agendas.

\section{The Subsidiarity Principle and frameworks for action}

The strength of the subsidiarity principle currently seems to impede the adoption of common strategic rules and principles guiding cultural tourism at a European level. Voluntary schemes and guidance systems aim to improve the management of cultural tourism. Examples include European eco-labelling, local agenda 21, WTO guidance or integral quality management of urban tourism. However, all of these schemes lack any constraining authority. This appears problematic as impacts upon cultural heritage often prove irreversible, while local authorities tend to underestimate negative impacts of tourism and often focus on its shortterm economic benefits. 
PICTURE surveys bring to light the overwhelmingly attractive and positive image of tourism within small-and-medium-sized towns. However, they also highlight knowledge gaps, lack of attention for impacts assessment, holistic or long term approaches. Strikingly, the more mature a tourist destination becomes, the more nuanced the positive connotations of tourism become. In our survey, for instance, one fifth of developing destinations nuanced their answers and half of mature towns tuned down their optimism. ${ }^{5}$

Without the proper tools for assessing and preventing negative impacts of tourism, countries lose control over and very often, benefits of tourist developments to the profit of private companies. This can lead to destruction of heritage, prettification, lost authenticity or subcultures rather than expected positive socio-economic impacts. For instance, the PICTURE project highlights that the development of cultural tourism can have very divergent impacts on the urban landscape. On the one hand, the growth of this industry can constitute a strong rationale for conserving a small town's remarkable skyline and natural environment, as it has been the case in the small city of Telc (Czech Republic). A counter-example can be found in the case of Česky Krumlov, that was nominated as UNESCO World heritage site the same year as Telč (1992). In this latter case though, the urban landscape was largely altered by new tourist facilities, new buildings and changes in public spaces. There is a risk that the nature of the place passes from a heritage to a mere attraction site whose image is largely driven by consumers' demands (Zukin, 1993, Urry 1990). The city of Amiens (France) is another interesting case as the recently adopted tourism strategy fostered a deep reinvestment in the urban landscape of the city. Still the Perret tower, a modern building of the 1950s, is now threatened for deterring the image of the city, while, though not meeting current criteria of 'sexy architecture' it certainly contributes to the identity of the city. The balance between integration in the landscape and promotion of the local (built) diversity therefore proves very difficult for many tourism destinations but it is also a source of cultural diversity, as it reflects different eras, and different backgrounds and is approached in diverse ways throughout Europe.

${ }^{5}$ More information on this can also be found in Deliverable 3 of Picture Project: Multi-dimensional matrix of impacts, by Dumont, Ruelle, Teller to be found on www.picture-project.com/ in the 'deliverables' section. 
It has to be further stressed that landscape concerns largely extend beyond aesthetic considerations. In the case of Telč, special efforts had to be made in order to preserve a balance between services for the tourists and for the local population. Obviously the mix of services and uses of public spaces forms part of the identity of a place. Unfortunately such factors are sometimes disregarded in large rehabilitation projects, concentrating heavily on the upgrading of the physical environment with few, if any, resources for supporting the social and cultural fabric of the locality. Aware of this issue, the city of Syracuse (Italy) is now directing part of local and European funds allocated to the development of tourism towards educational and cultural projects.

Indeed, in many places where large, organised cultural enterprises have seen the light, there are complaints about the obliteration of alternative cultural offers as funding is canalised to these enterprises. These are usually partly financed by public monies, which leaves little room for the expression of local artists, sometimes less fancy or marketable, or artists who do not share the same vision of culture as that put forward by the authorities (Massart, 2004, Delgado Ruiz, 2000). Bilbao’s Guggenheim, this icon of cultural tourism, has 'been criticised for taking over most of Bilbao's public budget for cultural activities (Zallo 1995)' (Gomez \& Gonzalez 2001), while its franchise aspect restricts choice of art exhibited, which is not made at local level or in a participative manner. Culture and heritage become commodities, mere instruments in the consumption game. They increasingly develop into a top-down business model, with elites deciding what needs to be produced and sponsoring it, according to expected profitability. The needs and desires of locals are often disregarded and cultural diversity disappears in the search for the typical or the need to produce one profitable type of artefact (Lask, 2005).

According to a high official from the secretariat of the Committee for Culture and Education at the European Parliament, however, problems arise more from a lack of budget than a lack of will. He insists that currently, only 7 cents per European citizen goes to culture while he argues that more than ten times that amount would be necessary to answer all demands. In such a situation, priorities appear of utmost importance and the crucial questions are who makes decisions on funding and spending: for example on a big eye-catching project or a variety of small local and discrete projects? There is a lot of demand from associations and organisations to provide funds or assistance, the Committee for Culture wants 
to intervene and display more proactivity but the subsidiarity principle impedes many of these actions, at least in the short term.

The choice of cultural activities and the treatment given to culture depends on the Member States but some effort is being made to influence specific Member States. For instance, a resolution can be adopted in the Parliament to try and stop some practices and without singling out one state, it is possible to use informal negotiations or bilateral agreements to preserve cultural diversity in spite of national policies. Such negotiations and resolutions recommend a set of actions. They do not bear any constraining effect, yet political consequences. The subsidiarity principle is not as strict as it seems but it still exerts power. It prevents immediate progress but 'we should give time to try and find a procedure that suits everybody and answers all expectations' (Interview high official in the Committee for Culture and Education at the European Parliament, January 2006)

\section{European Capitals of Culture Programme as an incentive for strategic planning}

The policy of European Capital of Culture included in the Culture 2000 framework has an impact beyond the local level, such as regional and international consequences. It allows regeneration within the chosen towns and emphasising European elements across the continent, since there is an obligation to emphasise Cultural Europe (rather than the culture of Europe).

This however, can create problems, as non European influences can be disregarded in the bid. For instance, the brochure about Mons 2015 puts the emphasis on European references while others receive hardly any attention. In the brochure explaining why it thinks it deserves to become European capital of Europe, the names of different artists are given who 'have brought a stone to European culture' (6). ${ }^{6}$ The brochure repeatedly highlights European connections and obliterates, for instance, the different waves of migration that Mons witnessed over the past centuries. ${ }^{7}$ Only at one point does the official prospectus mention that 'the project favours dialogue between cultures of Europe and other cultures

${ }^{6}$ From Mons: capitale européenne de la culture en 2015. All quotations in this paragraph come from this brochure unless otherwise mentioned.

7 'Mons 2015, an eminently European project' (9) or 'the project puts forwards cultural currents common to all Europeans' (10) or 'the project establishes long term cultural cooperations and favours circulation within the Union' (11). 
of the world' (15), but this takes the form of musical festivals 'pretexts to discover culture, gastronomy or the communities of these countries implanted here' (15). On the one hand, this means reducing them to the "other", setting them on display as the exotic to be watched, tasted and discovered but never closes enough to be really part of the project and shaping it. On the other hand, surveys about quality of life and festivals carried out in the context of the PICTURE project evidence that this specific festival is hardly known within the population of Mons.

The jury deciding on the towns chosen for European Capital has to make sure that an equilibrium is reached between local, European and international influences, as well as between ambitious projects and local benefits. Capitals of Culture offer unique opportunities for cultural development on a large scale and bring benefits to the towns chosen. However, the procedure and criteria could be revised, first to make application and designation procedures easier, second to not allow political ambitions to overshadow the cultural dimension and integrate better long-term impacts (Palmer/RAE Associates, 2004). More guidance for candidate towns also proves necessary, as well as a system that would allow bidding towns to learn from past capitals and work in networks with good practices (Interview high official in the Committee for Culture and Education at the European Parliament, January 2006).

Research shows, however, that the bidding process itself and the fact that countries can only bid at a specific time, motivates towns to elaborate strategic cultural tourism plans that have benefits beyond the event, in terms of impact and their length. In Mons, for instance, the desire to bid has led to the development of a strategy (2004) for a new town project, auditing qualities and challenges and suggesting different axes of development for at least the coming decade. It is still unknown whether Mons will be successful in this enterprise. Belfast however offers us a good example of the importance of the bidding process. After failure, it was realised that the bidding process itself had major significance for the town, as it triggered many elements such as 'joint working, cross-community discussion and a coming together of the city's cultural resources' (Sutherland 2006:2). It was therefore decided to continue working in that direction (i.e. for the development of cultural tourism with local participation) and this gave way to the launch of a Cultural Tourism Strategy by Belfast city council in 2003. Capitals of culture play a significant role in sustainable development since they force towns to think in the long term 
and develop strategic plans. It is therefore very important to have specific criteria that foster sustainable development and make sure culture gets a prominent role alongside with political or economic factors.

\section{Conclusion}

Cultural diversity plays a central and unique role in EU cultural policies. This finds its most significant expression in the subsidiarity principle that prevents any general or centralised law or regulation about culture and leaves. The aim is to lead to a flowering of cultures rather than to globalisation and uniformity. Even though the construction of Europe started as an economic enterprise, culture now plays an increasing role. Its importance as a cohesive force, a vector of development has been realised, as well as the wealth constituted by the diversity of European cultures. This has given way to different actions such as European Capitals of Culture and the need to take culture into account for any action that will influence it. The specificity of EU policies then seems to lie, on the one hand, in the absence of rigid rules and on the other hand, in transversality

Even though this has the benefits of allowing freedom to the Member States, research on interdisciplinary questions such as cultural tourism shows that it can also mea that Member States or their components have to respond to a situation they do not always master, without the proper tools or guidance to face the challenges. Small and medium-sized towns in Europe often resort to tourism in the hope of economic revitalisation but lack the tools or resources to develop it in sustainable ways. They ask more than anything for guidance and funding from the European Union, rather than being left to their own devices. In the absence of support, the very cultural diversity that is aimed to be protected is actually endangered, as is evidenced in the cases mentioned.

At the moment, the European Union plays a role of global monitoring through diverted methods, such as keeping an eye on developments and reacting through resolutions, lobbying, negotiations or bilateral agreements. This article argues for more guidance and tools for development of tourism for the protection of cultural diversity. If such tools cannot be made compulsory, they can at least be made available and incentives could be provided for their use. That would mean, for instance, increasing the budget of culture. 
Moreover, explicit and strong criteria in the different cultural actions are important in keeping in line with sustainable development. It also proves important to ensure that culture remains at the centre of such actions, not only economy or politics.

Admittedly, strict criteria and general guidelines can restrict freedom but guidelines can improve awareness, foster sustainability and lead to European integration and cooperation. This is more helpful than leaving members prey to the forces of globalisation or the survival of the fittest. In times of European expansion and the danger of a two-speed Europe this appears of utmost importance.

\section{References}

Ashworth, G.J. 2001. Conservation of the Built Environment in the Netherlands. In the Construction of Built Heritage: A North European Perspective on Policies, Practices and Outcomes, edited by Phelps \& Johannson. London: Ashgate.

Batt, Judy. 2001. EU Citizenship and pan-Europeanism. In Interlocking Dimensions of European Integration, ed. Helen Wallace, 265-283. Basingstoke: Palgrave.

Commission of the European Communities (CEC). 1996 a. first report on the consideration of cultural aspects in european community action - com (96) 160, commission of the european communities, Brussels.

Commission of the European Communities (CEC). 1996 b. cohesion policy and culture. a contribution to employment - com (96) 512, commission of the european communities, Brussels.

Commission of the European Communities (CEC). 1996 c. environmental impact assessment - guidance on scoping, european commission, directorate general - environment, nuclear safety and civil protection, may 1996.

Commission of the European Communities (CEC). 1996 d. proposal for a council directive on the assessment of the effects of certain plans and programmes on the environment - com (1996) 511 final, Brussels.

Commission of the European Communities (CEC). 1998. First Framework Programme in support of Culture (2000-2004) - COM (1998) 266, Brussels.

Cia, Blanca. 2004. Los vecinos de los barrios de Diagonal Mar, Maresme y Besos piden compensaciones por el impacto del Forum. El Pais Catalunya. 27 May.

Cities and local governments for cultural development. 2004. Agenda 21 for culture; www.agenda21cultura.net [accessed 3/12/2004],

Delgado Ruiz, Manuel. 2000. Usos sociales y politicos del turismo cultural. In J. Larossa \& C. Skliar (eds), Habitantes de Babel. Politica y poéticas de la diferencia. Barcelona: Laertes, 245-276. 
Cram, Laura. 2001. European Identity and National Identity in Central and Eastern Europe. In Interlocking Dimensions of European Integration, ed. Helen Wallace, 248-265. Basingstoke: Palgrave.

Dumont, Elisabeth, Ruelle, Christine \& Teller, Jacques. 2004. Multidimensional Matrix Gathering of Impacts, Methods and Policy Measures. Deliverable 3 of 'Picture Project,' www.picture-project.com/

Dumont Elisabeth, Teller Jacques, Origet du Clouzeau, Claude. 2005 'Pour une definition européenne du tourisme culturel' in Espaces, 231, novembre: 14-17.

Dumont Elisabeth, Teller Jacques, Origet du Clouzeau, Claude. 2004. 'Circumscribing Cultural Tourism: Towards a Criteria-based Approach' Picture Position Paper to be downloaded on www.picture-project.com.

Forum Européen pour les Arts et le Patrimoine (FEAP). 2004. Culture et Regions d'Europe. Premiers elements d'étude sur les politiques culturelles des Régions d'Europe. Lille: Conseil Régional du Pas de Calais.

Gomez, Maria \& Gonzalez, Sara.2001. A reply to Beatriz Plaza's 'The Guggenheim-Bilbao Museum Effect'. International Journal of Urban and Regional Research, 25(4), 898-900.

Guicheney, Jean-Claude \& Rouzade, Gérard. 2003. Le tourisme dans les programmes européens. Paris: La Documentation française.

International Council of Museums and Sites (ICOMOS). 2002. Inernational Cultural Tourism Charter. Principles and Guidelines for Managing Tourism at Places of Cultural and Heritage Significance. ICOMOS International Cultural Tourism Committee.

Lask, Tomke. 2005. Protecting the Golden Goose Without Stuffing it or How to Create Efficient Policies to Protect Intangible Heritage. Draft of June 2005 keynote speech for UNESCO gathering on cultural tourism in Riga.

Massart, Guy (2004) Commentaries on D3 : Multidimensional Matrix Gathering of Impacts, Methods and Policy Measures. Unpublished commentaries.

Palmer/RAE Associates . 2004. 'European Cities and Capitals of Culture' Study Prepared for the European Commission, can be downloaded on europa.eu.int/comm/culture/eac/sources_info/studies/capitals_fr.html.

Pire, Jean-Miguel. 2002. Pour une politique culturelle européenne, Notes de la Fondation Robert Schuman, Note 1.

Richards, Greg. (ed.) 1996. Cultural Tourism in Europe. Wallingford: CAB International.

Sørensen, Henning \& Vaever, Ole. 1992. State, Society and Democracy and the Effect of the EC. In Denmark and EC membership evaluated, ed Lise Lyck, 1327. London: Pinter.

Sutherland, Margaret. 2006. 'Belfast - Unsuccessful Bidding Candidate for 2008' unpublished notes to be further included in Deliverable 16 of the PICTURE project, available on www.picture-project.com.

United Nations Development Programme (UNDP). 2004. Cultural Liberty in Today's Diverse World. Human Development Report. New York : UNDP. 
United Nations Educational, Scientific and Cultural Organisation (UNESCO). 2002. Preliminary draft of a convention on the protection of the diversity of cultural contents and artistic expressions. CLT-2004/CONF.201/CLD.2.

United Nations Educational, Scientific and Cultural Organisation (UNESCO). 1994. Tourism and Cities of Art: The Impact of Tourism and Visitors Flow Management in Aix-en-Provence, Amsterdam, Bruges, Florence, Oxford, Salzburg and Venice. Venice: UNESCO regional office for Science and Technology for Europe. United Nations Educational, Scientific and Cultural Organisation (UNESCO). 2000. Universal Declaration on Cultural Diversity.

Urry, John. 1990. The Tourist Gaze: Leisure and Travel in Contemporary Societies. London: Sage.

Ville de Mons. 2004. MONS : Capitale européenne de la culture en 2015.

World Tourism Organisation (WTO). 2004. Outbound Tourism - International Tourist Arrivals by generating region www.world-tourism.org/facts/trends/ outbound.htm.

World Tourism Organisation (WTO). 2004. World Tourism Barometer, 2(3):1-3. www.atlas-euro.org/; [accessed 25/01/2005].

www.mons.be ; [accessed 1/12/2004].

Zukin, Sharon. 1993. Landscapes of Power: from Detroit to Disneyworld. Berkeley: University of California Press. 